\title{
Genealogi Gerakan Ikhwan Al Muslimin dan Al Qaeda di Timur Tengah
}

\author{
Rijal Mamdud \\ Pascasarjana UIN Sunan Kalijaga Yogyakarta \\ Email:rijalmamdud3@gmail.com
}

\section{ABSTRACT}

Historically, the rise of terrorism by radical Islamic groups in the Middle East has its roots in the spirit of resistance to Western colonialism in the early nineteenth century. There are two movements that have a big influence and inspire the emergence of similar movements in the Middle East, the Ikhwan AIMuslimin (IM) and AI Qaeda (AQ). This paper examines the roots of IM and Al Qaeda movements, and how the powerknowledge relation takes place. The theory used in this research is genealogy which seeks to examine the historical aspect and its relation to the formulation of power and politics; as well as the theory of Islamism, namely describing aspects of Islamic ideology, Islamic political movements, and socio-economic aspects. The findings of this article explain that IM and $A Q$ have historically been rooted in the resistance movement against the West. Sayyid Qutb's thoughts became the initial inspiration for the radicalization of IM activists, such as Muhammad Faraj, Ayman Al Zawahiri, and Osama bin Laden, so they built more extreme militias, such as Al Jihad and Al Qaeda. IM was originally a social organization and eventually involved in practical politics. Methods of Islamic movement based on cultural approach make IM widely accepted by Egyptian society, so that ever managed to win in election and be in elite circle of power. On the contrary, $A Q$ is conducting a resistance movement againts the West as well as governments in Muslim countries that are considered anti-Islamic by the method of terror, so it always marginal in public opinion of Muslim society.

Keywords: Al Qaeda, genealogy, Islamism, Muslim Brotherhood, political movement 


\section{ABSTRAK}

Secara historis, munculnya terorisme yang dilakukan kelompok-kelompok Islam radikal di Timur Tengah berakar pada semangat perlawanan terhadap kolonialisme Barat pada awal abad ke-19. Ada dua gerakan yang memiliki pengaruh besar dan menginspirasi kemunculan gerakan-gerakan serupa di Timur Tengah, yaitu Ikhwan Al Muslimin (IM) dan Al Qaeda (AQ). Artikel ini bertujuan untuk mengkaji akar gerakan dari organisasi Ikhwan Al Muslimin dan Al Qaeda, serta bagaimana relasi kuasa-pengetahuan yang terjadi. Teori yang digunakan dalam penelitian ini adalah genealogi yang berupaya mengkaji aspek sejarah dan hubungannya dengan formulasi kuasa dan politik; serta teori Islamisme, yaitu menguraikan aspek ideologi Islam, gerakan politik Islam, serta aspek sosial-ekonominya. Temuan artikel ini menunjukkan bahwa IM dan AQ secara historis berakar pada gerakan perlawanan terhadap Barat. Pemikiran Sayyid Qutb menjadi inspirasi awal bagi radikalisasi aktivis IM, seperti Muhammad Faraj, Ayman Al Zawahiri, dan Osama bin Laden sehingga mereka membangun milisi yang lebih ekstrim, seperti Al Jihad dan Al Qaeda. IM pada awalnya adalah organisasi yang bergerak dalam bidang sosial dan akhirnya melibatkan diri dalam politik praktis. Metode gerakan Islam yang berbasis pendekatan budaya menjadikan IM diterima luas oleh masyarakat Mesir, sehingga pernah berhasil menang dalam pemilu dan berada di lingkaran elit kekuasaan. Sebaliknya, AQ melakukan gerakan perlawanan terhadap Barat sekaligus pemerintah di negara-negara Muslim yang dinilai anti-Islam dengan metode teror, sehingga selalu marjinal dalam opini publik masyarakat Muslim.

Keyword: Al Qaeda, genealogi, gerakan politik, Ikhwan Al Muslimin, Islamisme

\section{Pendahuluan}

Dunia Islam abad ke-18 dan 19 ditandai dengan terbentuknya pola sistem masyarakat muslim global, yaitu sistem masyarakat yang dibangun berdasarkan hubungan antara nilai-nilai institusi negara Islam, keagamaan, dan institusi kultural masyarakat lokal. Meskipun perkembangan ini melahirkan tipe masyarakat Islam yang berbeda-beda, terdapat kemiripan corak kultural di antara mereka, karena dipertalikan oleh beberapa hubungan politik dan keagamaan, serta persamaanpersamaan nilai, (Lapidus, 2000:3). Islam telah menjadi suatu peradaban yang meninggalkan jejak di berbagai kebudayaan yang pernah didominasi olehnya, 
seperti bidang administrasi, hukum, ekonomi, dan sosial, serta aspek spiritual dan dogmatic, (Ali, 1995:3-4).

Dalam catatan sejarah, kekuatan Islam modern dapat dilacak dari kekaisaran Utsmaniyah (Ottoman). ${ }^{1}$ Kekaisaran Utsmani adalah representasi kekuatan adidaya dan bagian paling dikagumi oleh umat Islam di seluruh dunia saat ini, baik yang moderat maupun yang ekstrim, (Chaterwood, 2006:8). Kekaisaran Utsmaniyah menguasai wilayah yang terbentang dari Eropa hingga Asia. Di Eropa, kekuasaan Islam mencakup sebagian besar Semenanjung Balkan hingga daratan utara Hungaria. Di Asia, kekaisaran Utsmaniyah meluas ke wilayah Bosphorus hingga wilayah Iran dan Yaman di barat daya Jazirah Arab. Di Afrika, wilayah imperium Utsmaniyah terbentang dari pantai barat Laut Merah, Mesir, Libya, Tunisia dan Aljazair, (Imber, 2002:1).

Setelah berkuasa hampir delapan ratus tahun, kekaisaran Utsmaniyah hancur pada tahun 1924 sekaligus menandai munculnya Timur Tengah modern. Intervensi Eropa mengubah struktur internal masyarakat Muslim dan memunculkan konsep negara-bangsa. Bangsa Eropa yang mendominasi hampir seluruh wilayah Muslim melakukan pemaksaan institusi dan pola kultural mereka. Intervensi politik Eropa yang berlebihan memunculkan pola kontruksi negara-negara teritorial birokratik yang sentralistik. Sejalan dengan itu, penetrasi kelompok kapitalis Eropa menciptakan sistem perdagangan yang bersifat eksploratif, lebih berfokus pada produksi bahan baku untuk kepentingan industri Eropa, sehingga menimbulkan kerugian pada kegiatan industri local, (Lapidus, 2000).

Implikasi dari dominasi politik dan ekonomi Eropa terus berlangsung sampai sekarang. Pemerintahan kolonial dinilai merusak keseimbangan institusi sistem masyarakat pre-modern dan menimbulkan kemunduran kekuatan politik masyarakat Muslim di Timur Tengah. Kondisi tersebut melahirkan gerakan-gerakan yang memperjuangkan kepentingan Islam. Gerakan-gerakan ini memandang bahwa Islam harus menjadi fondasi negara dan nilai-nilai Islam harus ditegakkan secara penuh karena dianggap sebagai satu-satunya solusi dalam mencapai kejayaan masyarakat Muslim, sebagaimana spirit kesejarahan yang pernah tercatat pada masa lalu, (Ali, 2014:15). Kecenderungan untuk melakukan revivalisasi Islam ini sebenarnya sudah muncul sejak akhir abad ke-19 dan awal abad ke-20. Para pemikir Islam di masa itu menyesali kemunduran umat Islam dan menyalahkan pemahaman Islam klasik yang dianggap jumud. Kemudian muncullah semangat untuk mengembalikan kejayaan

$1 \quad$ Bangsa Eropa pada abad ke-17 menyebutkan bahwa kakaisaran Utsmaniyah sebagai kekaisaran Turki. Populasi Kekaisaran sangat heterogen baik struktur agama, Bahasa, dan sosial. Sebagai para imam, sultan, serta elit yang berkuasa, Islam adalah agama yang dominan. 
Islam dengan semangat kembali ke teks keagamaan untuk kemudian melakukan pembaharuan pemikiran agar dapat meredam ekspansi dunia modern. Maka lahirlah generasi baru yang berusaha merekonstruksi ulang ideologi politik yang berasaskan Islam dengan tujuan melawan kapitalisme dan imperialisme bangsa Eropa.

Dalam beberapa gerakan, ide mengembalikan kejayaan Islam justru dipahami melalui sentimen kebencian, dalam hal ini kebencian kepada eksistensi yang dianggap sebagai 'musuh Islam'. Mereka memiliki keinginan untuk memusnahkan "musuh" tersebut karena hanya dengan cara itu mereka dapat menegakkan sebuah sistem yang sesuai pandangan mereka, (Khan). Salah satu pemikir yang melahirkan berbagai kelompok radikal adalah Sayyid Qutb. la mengemukakan konsep 'jahiliyah'. Menurutnya, dunia yang hari ini berada dalam kondisi 'jahiliyah' karena tidak lagi menyembah Allah sebagai satu-satunya sesembahan dan tidak lagi mematuhi-Nya. Karena itu, Qutb mendeklarasikan bolehnya memerangi pemerintahan Muslim yang jahiliyah demi menegakkan Islam, (Rubin, 1990:36,50). Meskipun mendapatkan penentangan dari sebagian kalangan Ikhwan AI Muslimin sendiri, (Rubin, 1990:12,18) gagasan Qutb tentang gerakan Islam kontemporer telah melahirkan berbagai kelompok radikal yang berkeinginan untuk menjatuhkan pemerintahan negaranegara di negara Timur-Tengah, (Euben, 1966:8).

Kelompok-kelompok radikal di Timur Tengah ini kemudian menyebarkan pemikirannya ke berbagai negara lain, termasuk Indonesia. Dua kelompok besar yang berhasil menginfiltrasi pemikiran kaum Muslim di Indonesia adalah Ikhwan Al Muslimin dan Al Qaeda. Dalam penelitian ini, penulis akan mengkaji lebih dalam, akar gerakan Ikhwanul Muslimin dan AI Qaeda dengan harapan dapat dimanfaatkan untuk mencermati dan mencegah berkembangnya radikalisme di Indonesia.

\section{Landasan Teori}

\section{Genealogi}

Genealogi merupakan narasi sejarah yang menjelaskan sebuah aspek kehidupan manusia dengan menunjukkan bagaimana munculnya aspek tersebut. Narasi tersebut mungkin saja terbantahkan oleh sebagian fakta, atau spekulatif, tetapi yang pasti, selalu berkaitan dengan ruang historis kehidupan yang melingkupinya. Pembahasan mengenai genealogi selalu berhubungan dengan pemikiran Friedrich Nietzche tentang Genealogi Moralitas (Genealogy of Morals) dan Michael Foucault tentang disiplin dan hukuman (Discipline and punish). Genealogi adalah metode untuk menelusuri sejarah kritis yaitu cara menggunakan bahan-bahan sejarah untuk 
menghasilkan nilai revaluasi. Bagi Foucault dan Nietzsche, genealogi menyajikan alat untuk mengkritisi sebuah ide dan praktik dengan melacak sejarah kemunculannya, (Bevir, 2008).

Tujuan konsep genealogis dengan berusaha dan melacak akar sejarah, proses repurposisi darimana aspek praktisis kontemporer akan muncul, dan untuk menunjukkan kondisi historis keberadaan yang menjadi dasar praktik masa kini. Genealogi memandang sejarah sebagai hasil dari proses kekuasaan dan pertarungan karena dominasi dan telah dibentuk oleh hubungan kekuatan dan perjuangan yang kompleks. Dengan demikian, genealogi berusaha untuk membangun kembali berbagai sistem dan upaya untuk melawan dominasi, (Garland, 2014:372).

Sementara itu, Ritzer (2003) menjelaskan bahwa proses genealogi adalah melacak bagaimana serangkaian pengetahuan terbentuk dan analisis hubungan kesejarahan antara kuasa dengan pengetahuan; namun bukan menyelidiki suatu konspirasi melalui kesadaran aktor-aktornya, (George, 2003:78-80).

\section{Islamisme}

Menurut Emmanuel Sivan, Islamisme dapat dipahami sebagai sebuah reaksi perlawanan terhadap modernitas serta kegagalan rezim liberal dan kalangan nasionalis dalam mengatasi berbagai masalah sosial dan ekonomi yang dihadapi sejumlah negara. Islamisme, atau pemikiran fundamentalisme Islam, lahir sebagai cerminan kegagalan intelektual kiri dan rezim progresif dalam menawarkan alternatif solusi dari masalah yang dihadapi masyarakat. Ketidakmampuan rezim dalam mengatasi masalah negara mendorong sebagian pemikir fundamentalis Islam untuk kembali pada doktrin agama, (Euben, 1966:30). Pendekatan Islamisme dapat dikelompokkan menjadi tiga aliran pemikiran, (Ranko, 2012:18-21) yaitu:

\section{1) Pendekatan kulturalis (culturalist approach)}

Pendakatan kulturalis mengkaji tentang gagasan Islam sebagai satu kesatuan. Keyakinan paling menonjol dari pemahaman ini adalah bahwa hubungan antara agama dan negara tak terpisahkan. Kolonialisme, pengaruh politik, ekonomi, dan budaya, dipandang sebagai penyebab hilangnya budaya dan moral Islam. Fenomena Islamisme saat ini digambarkan untuk menegaskan kembali gagasan historis yang terus berlanjut dan sebagai upaya menuju keaslian budaya dalam menghadapi Barat. 
2) Pendekatan sosiologi dan ekonomi-politik (sociological and political-economy approach)

Pendekatan ekonomi-politik berakar pada kegagalan negara-negara Muslim dalam mewujudkan pembangunan ekonomi dan peningkatan standar hidup, gagal menjamin hak dan kebebasan politik setiap warga negara. Pendekatan sosiologi dan ekonomi-politik mempelajari latar belakang kondisi sosial-ekonomi dan aspek sosiopsikologis dari gerakan Islamis. Pendekatan ini sampai pada sebuah kesimpulan bahwa keterasingan sosial, subodinasi, dan isolasi menjadi penyebab individu untuk bergabung dengan kelompok Islam.

\section{3) Pendekatan gerakan sosial (social movement approach)}

Pendekatan ini melihat bahwa transformasi sosial membawa pola perjuangan yang didasarkan pada tipe organisasi. Studi Islamisme melalui gerakan sosial berusaha menemukan dorongan individu bergabung dalam gerakan Islam dan mempelajari bagaimana pemimpin organisasi mengelola pandangan dan harapan mereka.

Dalam artikel ini, peneliti hanya akan memfokuskan pada pendekatan pertama (culturalist approach).

\section{Sejarah Lahirnya Ikhwan AI Muslimin dan AI Qaeda}

\section{a. Ikhwan Al Muslimin}

Ikhwan Al Muslimin (Jam'iyyyat al-lkhwan al-Muslimin) didirikan oleh Hasan Al Banna pada tahun 1928. Al Banna menjalani pendidikan konservatif sederhana di pedesaan Mesir sehingga pada masa itu ia terasing dari kehidupan perkotaan yang luas seperti Kairo dan Alexandria. Ayahnya adalah seorang pemuka agama bernama Syaikh Ahmad Abd Al Rahman Al Banna Al Sa'aluti (1881-1958) dan seperti kebiasaan masyarakat Mesir, Al Banna mengikuti jejak langkah bapaknya, menekuni pendidikan agama, (Zahid, 2010:60-61). Setelah lulus dari Dar al-Ulum pada tahun 1927, ia ditunjuk oleh Kementerian Pendidikan sebagai guru bahasa Arab di sekolah dasar di Ismailiya.

Di tempat inilah ia mulai mengamati besarnya masalah sosial ekonomi yang dihadapi masyarakat Mesir, serta kuatnya dominasi asing dalam mengeksploitasi perekonomian negerinya. Orang-orang Eropa yang menjadi manajer di perusahaan Terusan Suez menjalani kehidupan yang mewah, sementara orang Mesir tinggal di 
tempat menyedihkan. Al Banna pun tergerak untuk memberikan pencerahan kepada masyarakatnya, menyadarkan masyarakat atas masalah yang sedang dihadapi, dan menawarkan solusinya, yaitu kembali kepada nilai-nilai Islam. Al Banna pun mendirikan Ikhwan Al Muslimin (IM) di Ismailiya tahun 1928 dan pada tahun 1930 IM telah memiliki lima kantor cabang. Pada tahun 1932, IM berkembang menjadi 15 cabang dan pada tahun 1938, menjadi 300 cabang. Meskipun jumlah anggota tepatnya tidak diketahui, 300 cabang mewakili antara 50.000 sampai 150.000 anggota.

Dengan demikian, dalam waktu yang singkat, IM secara signifikan meningkatkan jumlah cabang dan anggotanya. Hal ini disebabkan oleh tiga faktor utama. Pertama, IM memberikan layanan kepada masyarakat, seperti layanan pendidikan bagi laki-laki dan perempuan, perawatan medis yang murah, bantuan keuangan dan keterampilan kerja dengan skema pelatihan, (Zahid, 2010:60-61). Penyediaan layanan membawa jutaan warga Mesir terhubung langsung dengan IM dan yang paling penting adalah IM menunjukkan kemampuannya menyampaikan sebuah janji perbaikan sosial dan ekonomi kepada penduduk Mesir.

Selama periode tahun 1930-an, IM bergerak sebagai lembaga sosial, dengan aktivitas yang didominasi oleh reformasi moral dan spiritual masyarakat. Namun setelah itu, terjadi transisi gerakan yang menunjukkan aspirasi politik IM, yaitu keinginan untuk terjun dalam politik berorientasi pada pemerintahan. Langkah Al Banna bertujuan mengakhiri sistem partai dan mengarahkan komunitas politik pada satu arah yaitu interpretasi teologis teks-teks Islam. Dalam pandangan Al Banna, sebuah sistem partai politik berbahaya, penyebab perselisihan dan kejahatan dalam masyarakat, dan mengancam jalinan masyarakat Islam. Transformasi IM dan keterlibatannya dalam ranah politik bertujuan untuk memperkuat hubungan antara kalangan Islam di negara lain, terutama di seluruh wilayah Arab, sehingga menghidupkan kembali gagasan Khilafah Islam, (Zahid, 2010:60-61).

Kedua, munculnya pemikiran radikal yang mendorong perlawanan frontal terhadap rezim yang dipandang telah menyengsarakan rakyat. Pemikiran ini dibawa seorang pemikir bernama Sayyid Qutb. Qutb awalnya adalah pegawai negeri di Kementerian Pendidikan yang dikirim untuk belajar ke AS selama dua setengah tahun. Masa tinggalnya di AS telah memunculkan pemikiran perlawanan terhadap Barat yang disebutnya 'jahiliyah'. Pada tahun 1951, Qutb kembali dari AS, bergabung dengan IM, dan segera menjadi tokoh penting dalam struktur IM. 
Pandangannya kerap kali mengkritisi nilai-nilai kebebasan, individualisme, dan materialisme yang membentuk basis fungsional masyarakat Amerika. Dia percaya bahwa nilai-nilai ini adalah penyebab dari masalah sosial yang dihadapi oleh Amerika, seperti tingginya konsumerisme, diskriminasi seksual, dan pergaulan bebas. Sayyid Qutb percaya bahwa Amerika berada dalam keadaan jahiliyyah (kebodohan), (Zahid, 2010:60-61).

Dalam periode 1951-1954, Qutb menjadi salah satu anggota dewan pimpinan IM dan ia menyebarkan pemikiran radikal di tengah aktivis IM. la memandang bahwa pemerintah Mesir tidak Islami, jahiliyah, sehingga harus dilawan agar mau menerapkan sistem Islam dalam pemerintahan. Kritikan-kritikan terbuka yang dilakukan Qutb membuatnya ditahan pada tahun 1954 dan divonis 25 tahun penjara atas tuduhan makar.

Di saat Qutb mengalami penyiksaan dalam penjara, publik Mesir tengah merayakan nasionalisasi Terusan Suez, sikap tegas Presiden Mesir, Gamal Abdul Naser terhadap Barat. Kepemimpinan Naser di tengah negara-negara Arab memunculkan kebanggaan pada rakyat Mesir. Pengalaman pribadi Qutb membuatnya tetap berpegang pada pendapatnya bahwa pemerintahan Mesir adalah jahiliyah dan harus dilawan. Pada periode ini, ia menulis buku yang menjadi rujukan utama kalangan IM, Ma'aalim fi al-tariq. Dalam buku ini ia menyerang nasionalisme Mesir dan Arab, sosialisme, dan rezim Naser yang menurutnya menggabungkan semua ide yang sesat itu. Tahun 1964 ia dilepaskan dari penjara, namun beberapa bulan kemudian ditangkap kembali dan dijatuhi hukuman mati pada tahun 1966, (Rubin, 1990:49-50).

Meskipun Qutb sudah tiada, pemikirannya terus diduplikasi berbagai kelompok radikal di Mesir. Pada tahun 1970-an muncullah beberapa kelompok militan Islam yang terinspirasi dari pemikiran radikal Sayyid Qutb tentang takfirisme. ${ }^{2}$ Kelompok yang paling menonjol di antaranya adalah Military Academy Group yang dipimpin oleh Saleh Sirriyya, seorang Palestina, yang berusaha untuk menghasut pemberontakan di sebuah lembaga militer di pinggiran kota Kairo pada tahun 1974. Menurut pemimpin senior IM, penganiayaan brutal yang dialami oleh para anggota IM di kamp. penjara yang dilakukan oleh rezim Naser telah meyakinkan beberapa dari mereka bahwa rezim ini dan masyarakat yang mendukungnya tidak bisa lagi disebut sebagai Muslim; mereka adalah orang-orang kafir, (Wickhman, 2013:43).

Pandangan bahwa muslim, baik individu, kelompok, atau pemerintah yang tidak cukup menunjukkan komitmen terhadap Islam masuk dalam kategori kafir sehingga boleh diperangi. 
Meskipun beberapa tokoh IM sendiri banyak yang mengkritik pandangan radikal Qutb, di antaranya Al Hudaybi, semakin memburuknya kondisi sosial, ekonomi, dan politik Mesir semakin memperluas perkembangan paham radikal itu.

Ketiga, isu Palestina juga menjadi faktor penting dalam berkembangnya IM. Israel dideklarasikan tahun 1948 dengan berlandaskan Resolusi Dewan Keamanan PBB tahun 1947 yang memberikan sebagian tanah Palestina untuk dijadikan negara khusus Yahudi. Menurut IM, Israel adalah entitas yang didukung oleh semua kekuatan anti-Islam. Di saat yang sama, pandangan ini juga didukung oleh para ulama mainstream, misalnya ulama Al Azhar, 'Ali Jadd al Haqq, menyatakan bahwa kekuatan kolonial yang pernah menjajah negara-negara Arab masih ingin meneruskan penjajahan mereka dan melalui tangan Zionisme internasional, negaranegara Arab terus dipecah-belah." (Wickhman, 2013:112).

Pembelaan terhadap Palestina dan perlawanan terhadap Barat yang mendukung Israel pun menjadi salah satu isu utama yang berperan penting dalam rekrutmen IM di Mesir. Pada tahun 1948, IM menggalang dana, membeli senjata, mendirikan kamp. militer, dan mengirimkan petempur untuk berperang melawan Israel. Dan di saat yang sama, anggota IM membesar hingga lebih dari setengah juta orang. Isu Palestina pula yang akhirnya membuat pemerintah Mesir memutuskan untuk membubarkan IM. Sebagai respon, militan IM menembak Perdana Menteri Mahmoud Fahmi Nuqrashi. Rezim Mesir membalasnya dengan memerintahkan pembunuhan terhadap pemimpin IM, Hasan Al Banna pada Februari 1949. Peristiwa ini disusul berbagai aksi kekerasan lainnya dan ribuan aktivis IM kemudian dipenjarakan, (Rubin, 1990:11).

Pada era Anwar Sadat, konflik antara IM dan rezim semakin menguat. IM memandang bahwa perjanjian damai yang ditandatangani Sadat dengan Israel sebagai penghianatan bagi masyarakat muslim di Mesir. IM pun bangkit mengecam perjanjian Camp David pada 17 September 1978, mengecam perjanjian damai Mesir-Israel pada 26 Maret 1979, dan berkampanye melawan proses normalisasi hubungan Mesir-Israel pada Agustus 1979, (Rubin, 1990:19). Berbagai kerusuhan dan penangkapan terhadap aktivis Islam radikal (tidak hanya IM) terjadi pada masa ini. Sadat kemudian tewas dibunuh oleh anggota militer Mesir yang menjadi anggota kelompok radikal 'Al Jihad'.

Dalam gelombang Arab Spring, kekuatan IM berhasil naik ke puncak pemerintahan Mesir, dengan terpilihnya Mohammad Morsi sebagai presiden pada 
tanggal 30 Juni 2012. Namun, hanya selang setahun, ia digulingkan dalam aksi-aksi demo anti IM yang didukung militer. Pada 3 Juli 2013, Morsi dipaksa mundur dan pemerintahan Mesir kini berada di tangan Jenderal AI Sisi yang kemudian melakukan berbagai aksi represif terhadap aktivis IM. Kondisi ini semakin meradikalisasi aktivis IM dan banyak di antara mereka yang kemudian bergabung dengan kelompokkelompok radikal bersenjata, termasuk ISIS, (Hashem, 2014).

\section{b. Al Qaeda}

Al Qaeda (AQ) tidak bisa dilepaskan dari peran Osama bin Laden. la adalah anak dari seorang konglomerat bidang konstruksi Saudi asal Yaman. Bin Laden memiliki pandangan konservatif sejak usia muda dan ia telah mengadopsi pandangan militan Islam saat belajar di King Abdul Aziz di Universitas di Jeddah, Arab Saudi. Di sana ia selalu menghadiri ceramah Muhammad Qutb, saudara laki-laki Sayyid Qutb, yang menyebarkan pemikiran radikal Qutb, yaitu melakukan perlawanan revolusioner atau jihad untuk menegakkan Islam, (Rabasa, dkk, 2006:11). Osama bin Laden juga mendapatkan inspirasi dari Abdullah Azzam (aktivis IM Yordania) yang diidentifikasikan oleh beberapa ahli sebagai arsitek intelektual jihad melawan pendudukan Soviet 1979-1989 di Afghanistan, (Rollins, 2011).

Pada Oktober 2012, pemimpin AQ pasca tewasnya Osama bin Laden, Ayman Al Zawahiri, menyebarluaskan pesan video yang berisi pernyataan bahwa Bin Laden adalah anggota IM cabang Arab Saudi. Namun pada tahun 1980-an, ia dikeluarkan dari IM karena dia bersikeras untuk ikut berperang di Afganistan. Menurut Stephane Lacroix, peneliti aktivitas IM Arab Saudi, meskipun IM Saudi selalu tampil low profile untuk menghindari tekanan dari pemerintah, namun anggota IM Saudi-lah yang terbanyak bergabung saat Abdullah Azzam menyerukan jihad di Afghanistan, (Lacroix, 2013).

Bin Laden melakukan kunjungan pertamanya ke Afganistan beberapa tahun setelah invasi Soviet, Desember 1979, dan kemudian pindah ke daerah-daerah di Pakistan dekat perbatasan Afghanistan pada tahun 1986. la menggunakan sebagian dana pribadinya untuk membantu kelompok mujahidin Afghanistan dan melakukan perekrutan relawan dari berbagai negara Arab untuk berperang. Pada tahun 1984, Azzam dan Bin Laden membangun sebuah jaringan rekrutmen dan penggalangan dana di dunia Arab, Eropa, dan Amerika Serikat. Jaringan tersebut dinamai Maktab Al Khidmat, atau dikenal juga dengan Al Khifah. Banyak pengamat menilai bahwa 
Maktab adalah pelopor dari organisasi AQ. Tokoh utama lainnya dari Maktab yang berperan merekrut jihadis anti-Soviet adalah Umar Abd Al Rahman, pemimpin spiritual kelompok Islam radikal Al Jihad. Selain membantu di bidang dana dan rekrutmen, Bin Laden juga ikut berperang selama perang anti-Soviet; ia dilaporkan berpartisipasi dalam pertempuran tahun 1986 di Jalalabad dan serangan frontal April tahun 1987, (Lacroix, 2013).

Pada 11 Agustus 1988, Bin Laden bertemu dengan Ayman Al Zawihiri dan Dr. Fadl, dua aktivis IM asal Mesir, dan mereka bersepakat untuk membentuk AI Qaeda (AQ). Serangan bom pertama AQ terjadi pada tanggal 29 Desember 1992 di Hotel Gold Mihor, Aden (Yaman), yang menewaskan dua orang, (Wander, 2008). Pada tahun 1998, Osama mengeluarkan sebuah fatwa yang ditujukan kepada semua Muslim "yang menginginkan imbalan dari Tuhan harus mematuhi perintah untuk membunuh orang Amerika dan menjarah harta mereka dimanapun dan kapanpun mereka menemukannya". Osama Bin Laden dengan tegas mengatakan:

To kill the Americans and their allies, both civil and military, is an individual duty for every Muslim who is able, in any country where this is possible, until the al-Aqsa Mosque and the Haram Mosque are freed from their grip and until their armies, shattered and broken winged, depart from all the lands of Islam, (Orbach, 2001:60).

Dalam wawancaranya dengan salah satu media pada 1998, bin Laden semakin mempertegas dan mengatakan target jihad AQ adalah semua rakyat Amerika, "Kami tidak membedakan antara mereka yang berpihak dengan militer dan warga sipil. Mereka semua adalah target, jika rakyat Amerika tidak ingin dirugikan dalam negara mereka sendiri, mereka harus berusaha untuk memilih pemerintah yang benarbenar mewakili dan melindungi kepentingan mereka." Bin Laden juga melanjutkan, "Setiap orang Amerika yang membayar pajak kepada pemerintahannya menjadi target kami karena telah membantu perang Amerika melawan negara muslim." (Orbach, 2001:60).

Fatwa Osama Bin Laden berdampak luas terhadap arah gerakan kelompok jihadis, khususnya yang berafiliasi dengan AQ. AQ memiliki sel yang tersebar di lebih dari 60 negara, mulai dari Asia, Timur Tengah hingga Afrika dan Eropa. Sel-sel itu bekerja dalam struktur yang longgar dan bersifat lokal, dimana Al Qaeda berperan sebagai 'kapal induk' organisasi.

Pada 11 September 2001 terjadi serangan terorisme atau pengeboman 
terhadap gedung WTC (Peristiwa 911) dan AS menuduh AQ sebagai pelakunya. Sejak itu pula AS melancarkan Perang Melawan Terorisme untuk menghancurkan sel-sel AQ di berbagai penjuru dunia. Target utama AS adalah Osama bin Laden yang akhirnya tewas oleh serangan intelijen Amerika Serikat pada bulan Mei 2011. Setelah kematian Bin Laden, AQ kemudian dipimpin oleh Ayman AI Zawahiri.

Di bawah kepemimpinan Al Zawahiri, AQ berkonflik dengan ISIS. Awalnya, ISIS adalah cabang dari AQ di Irak, yang didirikan oleh Abu Mus'ab Al Zarqawi. Setelah kematian Bin Laden, pemimpin baru ISIS, Abu Bakr Al Baghdadi, mulai berbeda pendapat dengan Al Zawahiri. Baghdadi sering melakukan aksi-aksi tanpa persetujuan Al Zawahiri dan akhirnya memisahkan diri sepenuhnya dari AQ. ISIS kemudian ikut serta dalam perang Suriah dan berkonflik dengan AQ cabang Suriah (Jabhah AI Nusra). ISIS sempat berkembang melebihi AQ terutama karena berhasil menguasai wilayah-wilayah kaya minyak di Irak dan Suriah. Namun serangan militer AS, Rusia, dan Suriah membuat ISIS akhir-akhir ini semakin kehilangan kekuatan dan kekuasaannya.

\section{Hubungan Antara IM dan AQ}

Dari uraian sebelumnya, kita dapat melihat bahwa tokoh-tokoh AQ pada awalnya adalah bagian dari IM. Meskipun secara resmi para tokoh organisasi ini menyatakan bahwa kedua organisasi mereka berbeda, namun secara ideologis keduanya memiliki kesamaan cita-cita, yaitu revivalisasi Islam. Karena itulah salah satu kebijakan IM adalah menjalin hubungan dengan jaringan jihadis lainnya seperti jaringan AQ, Abu Mus'ab AI Zarqawi. IM menyetujui ideologi AQ, serta prinsip militansi dan permusuhannya terhadap Amerika. Sebagaimana dikatakan oleh Rajab Hilal Hamida, anggota IM di parlemen Mesir yang mengatakan, (Rubin, 2010:7):

From my point of view, bin Laden, Al Zawahiri and Al Zarqawi are not terrorists in the sense accepted by some. I support all their activites, since they are a thorn in the side of the Americans and the Zionists...(on the other hand) he who kills Muslims citizens is neither a jihad fighter nor a terrorist, but a criminal and murderer. We must call things by their proper names.

Ada tiga poin penting yang dapat digarisbawahi saat membandingkan IM dan AQ.Pertama, IM dan AQ sebagai representasi dua arus kekuatan fundamentalis saat ini di Timur Tengah dan sama-sama memiliki pengaruh besar di berbagai penjuru dunia, bukan dua entitas yang saling bermusuhan meskipun pada saat yang sama mereka 
bersaing untuk mendapatkan dukungan massa dan kekuasaan. Kedua, perbedaan paling penting di antara keduanya adalah bahwa $\mathrm{AQ}$ berfokus untuk menyerang musuh yang 'jauh', yaitu Israel, Amerika Serikat, dan Barat pada umumnya, sedangkan IM, meskipun anti-Israel dan anti-Barat, memfokuskan gerakannya pada "musuh dekat" yaitu pemerintahan negara-negara Arab di mana mereka beraktivitas. Ketiga, IM memiliki taktik fleksibel, terkadang bahkan bergabung dengan pemerintah, sementara AQ secara ekslusif berfokus pada perjuangan melalui peperangan langsung. Kelompok IM melihat revolusi sebagai sebuah upaya jangka panjang, sehingga mereka melibatkan layanan sosial dan pendidikan untuk membangun dukungan massa, melakukan doktrinasi kaum muda melalui institusi, berpartisipasi dalam pemilihan umum, serta terkadang berkompromi dengan pemerintah. Namun di tengah perbedaan ini ada persamaan ideologis mereka, yaitu sama-sama memiliki pandangan visioner mengenai implementasi nilai-nilai Islam dalam pemerintahan. Keduanya sama-sama memandang bahwa untuk mengalahkan dominasi Barat, umat muslim harus kembali kepada nilai-nilai Islam.

Secara umum, publik akan melihat bahwa AQ lebih berbahaya karena melakukan tindakan terorisme, sehingga jauh lebih kecil kemungkinannya untuk merebut kekuasaan negara, (Orbach, 2001:60). Sebaliknya, faktor taktik yang fleksibel dan cenderung ke arah politik praktis, membuat IM lebih mudah diterima oleh masyarakat.

\section{Ideologi Teror dan Relasi Kuasa IM dan AI Qaeda}

\section{a. Ikhwan Al Muslimin}

Sebagaimana telah disampaikan di landasan teori, analisis genealogi bertujuan memeriksa bagaimana rangkaian pengetahuan dibentuk dan dihubungkan dengan relasi kuasa. Gerakan IM lahir dalam kondisi ketika Mesir berada di bawah penjajahan Inggris. Inggris menjajah Mesir sejak 1882. Pada tahun 1919, menyusul revolusi Mesir, Kerajaan Mesir didirikan, namun secara de facto, Inggris tetap mengontrol segala hal, mulai dari urusan luar negeri, pertahanan, ekonomi, hingga pendidikan.

Di saat yang sama, posisi agama dan ulama Islam sangat besar di Mesir. Universitas Al Azhar di Kairo yang menjadi pusat keilmuan Islam di Timur Tengah hingga saat ini didirikan tahun 970. Al Azhar menjadi pusat pembangunan jaringan nasional pendidikan keagamaan dan ulama Mesir yang berperan penting dalam memelihara budaya Islam, dengan menciptakan mata rantai sosial dan moral yang 
kuat antara Kairo dan provinsi-provinsi lain. Karena itu pula, ulama memiliki peran menonjol dalam semua krisis politik yang dialami oleh Mesir, (Fuad, 2016).

Dalam situasi seperti inilah Hasan Al Banna menggunakan nilai-nilai Islam untuk melawan penjajahan, ketidakadilan ekonomi, dan masuknya gelombang gaya hidup budaya Barat dalam kehidupan masyarakat Mesir. Untuk melakukan perlawanan itu, Al Banna mendirikan Ikhwanul Muslimin (IM) tahun 1928 dengan pendekatan kultural. la menekankan bahwa pengelolaan negara harus didasarkan pada nilainilai agama. Dan penjajahan Inggris merupakan penyebab hilangnya budaya dan moral Islam.

Pada tahun 1953, Mesir lepas dari penjajahan Inggris dan menjadi Republik Mesir modern. Sebelumnya, tahun 1949, Hasan Al Banna dibunuh oleh rezim Mesir, menyusul konflik antara keduanya (pemerintah versus IM) terkait perlawanan terhadap Israel. Pasca Al Banna, 'pengetahuan' dalam tubuh IM mengalami pergeseran ke arah yang lebih radikal karena dominasi pemikiran Sayid Qutb. Di saat yang sama, rezim Mesir juga melakukan represi terhadap aktivis IM, dimana ribuan aktivis IM dipenjarakan dan sebagiannya dihukum mati. Pemikiran radikal juga semakin berkembang sebagai respon atas sikap represif ini.

Selama beberapa dekade, IM mengalami represi, pengawasan, dan pengucilan rezim. Di saat yang sama, situasi ini mendorong IM untuk membangun aktivisme, persatuan, kohesi, serta pendewasaan gerakan. Penindasan rezim berdampak pada keseimbangan kekuatan dalam organisasi, di antaranya; meningkatnya posisi faksi IM yang konservatif, garis keras, dan mengorbankan faksi yang lebih moderat. Faksi konservatif mengambil keuntungan dari tindakan represif dan mendelegitimasi seruan reformasi internal.

Aktivis-aktivis IM yang semakin teradikalisasi kemudian memisahkan diri dan membentuk milisi-milisi bersenjata. Di antaranya, Muhammad Al Faraj, yang sangat dipengaruhi oleh pemikiran Qutb mengenai pentingnya penghancuran 'musuh yang dekat' (yaitu pemerintahan sekuler di negara-negara 'jahiliyyah'), pada tahun 1980 mendirikan milisi Al Jihad (yang kemudian membunuh Anwar Sadat). Ayman Al Zawahiri dan Osama bin Laden, yang semula adalah aktivis IM juga memisahkan diri dan membentuk AQ pada 1988.

Setelah pembunuhan Sadat, IM mengambil jalur politik pragmatis, berusaha memisahkan diri dari orang-orang yang telah melakukan pembunuhan (AI Jihad) dan mendukung idealitas negara. Dengan demikian, cara IM secara gradual mengambil kesempatan dalam mendamaikan situasi regional Mesir. Aktivis Ikhwan Al Muslimin 
pun masuk parlemen dan institusi masyarakat sipil. Pencitraan IM di level negara pun makin positif, dipandang sebagai aktor yang memiliki tujuan mulia di ranah sosial, budaya, dan agama. Akan tetapi, pemerintah Mesir tetap enggan memberikan legalitas organisasi kepada IM, (Ranko, 2012).

Presiden Hosni Mubarak menghadapi pemilihan parlemen pertamanya pada tahun 1983. Untuk memastikan mayoritas dua pertiga kemenangan untuk NDP (National Democratic Party), undang-undang pemilihan diubah. Undang-undang baru tersebut membatasi aktivisme politik pada partai yang sah. Menurut undangundang ini, semua partai politik yang berpartisipasi perlu mencapai ambang suara sebesar delapan persen untuk mendapatkan kursi di dalam majelis rakyat. Ambang batas ini sangat tinggi dan untuk mencapainya pun sangat sulit. Bagi IM, satusatunya cara untuk bersaing dalam pemilihan adalah dengan beraliansi dengan partai oposisi sekuler. IM pun berkoalisi dengan Partai AI Wafd dan ini merupakan sebuah langkah berani dari pihak IM, mengingat perbedaan ideologis dan adanya sejarah konfrontatif di antara keduanya, (Zahid, 2010:98).

Koalisi dengan AI Wafd merupakan sebuah langkah besar dalam transisi gerakan agama ke politik. IM dan AI Wafd pada pemilihan parlemen berhasil menghasilkan 58 kursi pada Majelis Rakyat. Selain itu, kehadiran IM di parlemen menunjukkan kemungkinan untuk membangun peran kunci politik dan menjadi penantang baru bagi pemerintah. IM juga membentuk aliansi dengan Partai Al Amal dan partai Hizb Al Ahrar, salah satu partai liberal. Pada pemilihan parlemen 1995, IM berhasil mendapatkan 170 kursi dalam parlemen, (Zahid, 2010:98).

Ketika Mubarak menekan faksi-faksi Islamis dengan cara memposisikan kelompok-kelompok Islam dalam kerangka Islam yang "baik" dan "buruk", IM berupaya menempatkan dirinya sebagai kelompok moderat. Gerakan dan ideologi IM tidak diperlihatkan secara frontal dan mereka tetap bekerja di dalam institusi politik formal. Sementara itu, Mubarak berupaya memposisikan diri sebagai kekuatan Islam modern dan karena itu perlu melakukan pendekatan terhadap kelompokkelompok moderat. Selain itu, kebijakan liberalisasi politik yang dilakukan Mubarak juga menguntungkan IM, sehingga kehadirannya di tengah masyarakat sipil dan institusi negara semakin meningkat, (Zahid, 2010:98).

Momentumyang ditunggu IMuntukmencapaitujuan politiknya akhirnya tercapai pada Juni 2012 ketika pemilihan presiden Mesir pasca lengsernya Mubarakmembawa aktivis IM, Muhammad Mursi, ke tampuk kepresidenan. Mursi mendapatkan 51,7\% suara sementara penantangnya, Ahmad Shafiq (mantan perdana menteri pada era 
Mubarak) mendapatkan 48,3 \%. Ini adalah pemilu demokratis pertama yang dialami Mesir sekaligus pertama kalinya rakyat Mesir dipimpin oleh presiden berhaluan Islam.

Sejak awal, IM menyadari adanya ketakutan sebagian pihak terhadap ideologi mereka. "Kami adalah warga Mesir yang normal, kami bukan monster. Kandidat kami menang, dan kami akan pergi ke Tahrir Square dan berada di sana sampai semua tuntutan kita dipenuhi," kata Sameh Al Essawy, seorang pejabat kampanye IM. Kemudian, Mursi pun tampil di tengah kerumunan para demonstran di Tahrir Square untuk menunjukkan bahwa ia akan bersama rakyat dari semua golongan, (Kingsley, 2015).

Namun yang terjadi selanjutnya, IM teburu-buru melakukan perubahan politik tanpa memperhatikan kondisi Mesir serta kekuatan riil politik Mesir. Di sini, relasi pengetahuan dan kekuasaan kembali muncul dimana IM terlihat berusaha memaksakan pemikirannya melalui kekuasaan yang dipegangnya. IM telah mengabaikan kenyataan bahwa naiknya Mursi (IM) ke kursi kepresidenan berawal dari demo-demo anti-Mubarak yang tidak hanya dihadiri oleh aktivis IM, namun juga kelompok kiri, liberal, dan moderat. Terpilihnya Mursi pun tak lepas dari keengganan kelompok revolusioner untuk memilih lawannya, Ahmad Shafiq yang merupakan mantan perdana menteri pada era Mubarak.

Namun setelah berkuasa, IM berbalik memaksakan 'pengetahuan' segelintir faksi yang berada di lingkaran inti kekuasaan dan meninggalkan kelompok-kelompok lain yang berperan dalam revolusi. Di sisi lain, keberadaan anasir-anasir pro Mubarak yang telah berkuasa selama 30 tahun masih banyak yang memegang posisi penting dalam kekuasaan dan menginginkan kembalinya status quo. Dalam menghadapi mereka, IM seharusnya melakukan kerjasama dengan faksi-faksi revolusioner lainnya, namun hal itu tidak dilakukan.

Pemerintahan Mursi menyusun konstitusi baru yang kemudian disetujui oleh mayoritas parlemen (yang juga didominasi IM). Konstitusi baru ini dipandang oleh faksi-faksi revolusioner lain sebagai UU yang disusun demi kepentingan IM dan sekutu Salafi-nya, tidak demokratis, memungkinkan para ulama untuk campur tangan dalam proses pembuatan undang-undang, serta meninggalkan kelompok minoritas tanpa perlindungan hokum, (Beaumont dan Morsi, 2012).

Konstitusi baru ini menyebutkan bahwa "hukum Islam sebagai sumber dari pembuatan undang-undang", (Sabry, 2013). Selain itu, Mursi mendapatkan kekuasaan besar untuk mengintervensi prosedur pengadilan, sehingga ia secara 
sepihak bisa memutuskan digelarnya referendum publik untuk pengesahan UU baru ini. Akibatnya, muncul demonstrasi besar-besaran, disertai bentrokan antara kelompok IM melawan kelompok kiri dan liberal. Setelah demo berlangsung sepuluh hari, Mursi mengubah keputusannya, namun gelombang ketidakpuasan tidak bisa lagi dihentikan. Demo-demo anti pemerintah terus berlanjut, sampai akhirnya Mursi tumbang karena militer mengambil alih kendali. Dalam wawancara dengan Peter Kingsley, Mursi mengakui bahwa hal tersebut adalah kesalahan, "It was not meant to be, but it contributed some kind of misconception in society."(Kingsley, 2015).

Tumbangnya Mursi dan IM, yang disusul dengan pembunuhan lebih dari 800 aktivis IM oleh rezim Jenderal AI Sisi (Presiden Mesir pasca Mursi) memunculkan kembali radikalisme di kalangan IM sehingga banyak di antara mereka yang kemudian bergabung dengan kelompok-kelompok radikal bersenjata, termasuk ISIS, (Hashem, 2014).

\section{b. Al Qaeda}

Seperti dinyatakan Foucault, diskursus diproduksi dalam konteks sejarah, geografis, dan sosial-politik yang spesifik. Para pemilik kuasa membangun narasi yang sejalan dengan nilai yang diyakininya. Demikian pula yang terjadi dalam pembahasan mengenai ideologi teror Al Qaeda. Dalam hal ini, Al Qaeda akan selalu memproduksi narasi yang menempatkan diri sebagai korban dari imperialisme AS dan narasi-narasi perlawanan terhadap AS dengan berlandaskan ayat-ayat jihad, (Talbot, 2008).

Sebagaimana sudah dijelaskan sebelumnya dalam genealogi $A Q, A Q$ lahir dari para aktivis IM yang terpengaruh oleh pemikiran Qutb dan Faraj. Namun, bila Faraj memilih untuk melawan musuh yang dekat ('near enemy'), yaitu pemerintahan 'jahiliyah' yang berkuasa di negeri-negeri Muslim, AQ membangun narasi bahwa baik 'musuh yang dekat' maupun 'musuh yang jauh' (yaitu Barat, khususnya AS) harus sama-sama dilawan. "Setiap orang Amerika yang membayar pajak kepada pemerintahannya menjadi target kami karena telah membantu masih perang Amerika melawan negara muslim," demikian disampaikan Bin Laden, (Orbach, 2001:60).

Wakil Bin Laden, Ayman Al Zawahiri, dalam pesan video yang dirilis bulan Juni 2005 menyampaikan prinsip-prinsip inti AQ, yaitu; pertama, negara-negara Muslim harus dibebaskan dari penjajahan Barat, dan kontrol terhadap sumber energi di Timur Tengah harus kembali ke tangan Muslim, karena itu reformasi dan pemilihan 
umum sama sekali tidak ada manfaatnya sebelum pembebasan terjadi. Kedua, kaum Muslim harus berjuang dan menggulingkan pemimpin negara mereka yang melangga hukum Islam, (Blanchard, 2007).

Retorika anti-Barat di satu sisi menjadi senjata ampuh untuk mendapatkan perhatian dunia dan merekrut anggota dari berbagai penjuru dunia, namun di saat yang sama, AQ juga memusuhi sistem pemerintahan negeri-negeri Muslim. Akibatnya, aksi-aksi terorisme justru lebih banyak dilakukan AQ di negara-negara Muslim. Merespon hal ini, negara-negara Muslim pun aktif melakukan bebagai upaya deradikalisasi, di samping juga menangkapi para anggota AQ yang terlibat dalam aksi terorisme.

Di sini terlihat bahwa 'pengetahuan' yang dibangun AQ (mengenai penjajahan Barat dan perlawanan Islam) hanya berkorelasi dengan power yang terbatas dan dimiliki AQ; dan sebaliknya power yang dimiliki negara, terutama Barat, lebih efektif dalam menciptakan pengetahuan mengenai terorisme sehingga sebagian besar publik, baik negara-negara Muslim maupun Barat menolak AQ.

Sementara itu, dari perspektif pendekatan budaya (culturalist approach), AQ sama sekali tidak membangun jaringan ekonomi atau pelayanan publik sebagai IM. AQ menjadikan Islam sebagai fondasi ideologi sekaligus strategi pencapaian. AQ menciptakan narasi anti-Barat dan menawarkan Islam sebagai ideologi tandingan, namun tidak ada strategi budaya yang dibangun. AQ hanya mengedepankan teror sebagai strategi untuk mewujudkan idealismenya. Akibatnya, AQ tidak berhasil mendapatkan banyak dukungan publik dan tidak bisa mempengaruhi dinamika politik suatu negara, berbeda dengan IM yang pernah berhasil memenangkan pemilu dan mencapai lingkaran elit kekuasaan.

\section{Kesimpulan}

IM dan AQ secarahistoris berakar padagerakan perlawanan terhadap Barat.IMlahir ketika Mesir dalam keadaan terjajah oleh Inggris dan berlanjut pada pemerintahan lokal yang bekerjasama dengan Barat yang menyebabkan kesenjangan ekonomi yang dalam serta tersingkirnya nilai-nilai Islam dalam kehidupan masyarakat Mesir. Sementara itu, AQ lahir dari para aktivis IM yang terpengaruh oleh pemikiran Qutb dan Faraj.

AQ membangun 'pengetahuan' yang disampaikannya kepada publik bahwa negara-negara Muslim harus dibebaskan dari penjajahan Barat karena itu kaum Muslim harus berjuang dan menggulingkan pemimpin negara mereka yang bekerja 
sama dengan Barat dengan cara-cara ekstrim. Dari perspektif pendekatan budaya (culturalist approach), AQ sama sekali tidak membangun jaringan ekonomi atau pelayanan publik sebagaimana IM. AQ menjadikan Islam sebagai fondasi ideologi sekaligus strategi pencapaian. AQ menciptakan narasi anti-Barat dan menawarkan Islam sebagai ideologi tandingan, namun tidak ada strategi budaya yang dibangun. 'Pengetahuan' yang dibangun AQ hanya berkorelasi dengan power yang terbatas dan dimiliki AQ; dan sebaliknya power yang dimiliki negara, terutama Barat, lebih efektif dalam menciptakan pengetahuan mengenai terorisme sehingga sebagian besar publik menolak ekstrimitas $\mathrm{AQ}$.

Sebaliknya, IM membangun pengetahuan publik mengenai pentingnya penegakan kembali nilai-nilai Islam dalam pemerintahan melalui kegiatan-kegiatan sosial dan ekonomi yang menyentuh langsung kehidupan riil masyarakat. Karena itulah IM mendapatkan dukungan yang signifikan di tengah masyarakat Mesir dan berhasil memenangkan pemilu parlemen, serta mencapai lingkaran elit kekuasaan dengan terpilihnya presiden dari kalangan IM, Muhammad Mursi.

Namun yang terjadi selanjutnya adalah IM teburu-buru melakukan perubahan politik tanpa memperhatikan kondisi Mesir serta kekuatan riil politik Mesir. Di sini, relasi pengetahuan dan kekuasaan kembali muncul dimana IM terlihat berusaha memaksakan pemikirannya melalui kekuasaan yang dipegangnya. Akibatnya muncul perlawanan dari kelompok kiri, liberal, dan moderat, yang berujung pada tergulingnya Presiden Mursi.

\section{Daftar Pustaka}

Ali, A. (2014). Al Qaeda:Tinjauan Sosial-Politik, Ideologi dan Sepak Terjangnya. Jakarta: Pustaka LP3ES.

Ali, M. (1995). Alam Pikiran Islam Modern di Timur Tengah. Jakarta: Djambatan.

Beaumont, P. dan Morsi, M. (2012). Signs Egypt's new constitution into law. The Guardian, [online]. Dalam: https://www.theguardian.com/world/2012/dec/26 [Diakses 30 Nov 2017].

Bevir, M. (2008). What is Genealogy. Journal of the Philosophy of History, [online] 2, 63-275. Dalam: http://educationalfoundations.pbworks.com/f/What_ls_ Genealogy(2008).PDF. [Diakses 30 Nov 2017]. 
Blanchard, C. (2007). Al-Qaeda: Statements and Evolving Ideology. [online] FAS. Dalam: https://fas.org/sgp/crs/terror/RL32759.pdf. [Diakses 30 Nov 2017].

Chaterwood, C. (2006). A Brief History of The Middle East: From Abraham to Arafat. New York: Carroll \& Graf Publishers.

Euben, Roxanne L. (1966). Enemy in the Mirror Islamic Fundamentalism and The Limits of Modern Rationalism: A Work of Comparative Political Theory. New Jersey: Princeton University Press.

Fuad, A. (2016). Pergolakan Politik Mesir Masa Kolonial dan Dampaknya Terhadap Reformasi Hukum Keluarga Islam. Mahkamah: Jurnal Kajian Hukum Islam, 1 (2).

Garland, D. (2014). What is a history of the present? On Foucault's geneologies and their critical preconditions. Punishment \& Society, 16 (4).

George, R. (2003). Teori Sosial Post Modern. Yogyakarta: Kreasi Wacana.

Hashem, M. (2014). Sinai Campaign, a Boon to Islamic State. [online] Carnegie Endowment. Dalam: http://carnegieendowment.org/sada/57412. [Diakses 12 Jan 2018].

Imber, C. (2002). The Ottoman Empire 1300-1650: The Structure Power. New York: Palgrave MacMillan.

Khan, M. Islamic Fundamentalism. [online] Muslim Library. Dalam: http://www. muslim-library.com/dl/books/English_Islamic_Fundamentalism.pdf [Diakses 30 Nov 2017].

Kingsley, P. (2015). How Mohamed Morsi, Egypt's first elected president, ended up on death row. The Guardian, [online]. Dalam: https://www.theguardian.com/ world/2015/jun/01/mohamed-morsi-execution-death-sentence-egypt [Diakses 26 Jan 2018].

Lacroix, S. (2013). Osama bin Laden and the Saudi Muslim Brotherhood. Foreign Policy, [online]. Dalam: http://foreignpolicy.com/2012/10/03/osama-bin-ladenand-the-saudi-muslim-brotherhood/ [Diakses 18 Jan 2018].

Lapidus, I. (2000). Sejarah Sosial Ummat Islam Jilid II. Jakarta: Raja Grafindo Persada.

Orbach, B. (2001). Usama Bin Laden and al-Qaeda: Origins and Doctrines. Middle East Review of International Affairs, 5 (4). 
Rabasa, A, et.al. (2006). Beyond al-Qaeda: The Global Jihadist Movement. [online] RAND. Dalam: https://www.rand.org/content/dam/rand/pubs/monographs/2006/ RAND_MG429.pdf [Diakses 18 Jan 2018].

Ranko, A. (2012). The Muslim Brotherhood and its Quest for Hegemony in Egypt: StateDiscourse and Islamist Counter-Discourse. Germany: Springer VS.

Rollins, J. (2011). Al-Qaeda and Affiliates: Historical Perspective, Global Presence, and Implication for U.S Policy. [online] FAS. Dalam: https://fas.org/sgp/crs/terror/ R41070.pdf. [Diakses 30 Nov. 2017].

Rubin, B., Ed. (2010). The Muslim Brothehood: The Organization and Policies of a Global Islamist Movement. United State: Palgrave Macmillan.

Rubin, B. (1990). Islamic Fundamentalism in Egyptian Politics. United State: Palgrave Macmillan.

Sabry, B. (2013). 22 Key Points in Egypt's New Draft Constitution. Al-Monitor, [online]. Dalam: https://www.al-monitor.com/pulse/originals/2013/08 [Diakses 30 Nov 2017].

Talbot, S. (2008). Us' and 'Them': Terrorism, Conflict and Other Discursive Formations. [online] Sociological Research. Dalam: http://www.socresonline.org.uk/13/1/17. html [Diakses 26 Jan 2018].

Wander, A. (2008). A History of Terror. The Guardian, [online]. Dalam: https://www. theguardian.com/world/2008/jul/13/history.alqaida [Diakses 18 Jan 2018].

Wickhman, C. (2013). The Muslim Brotherhood: Evolution of Islamist Movement. London: Princeton University Press.

Zahid, M. (2010). The Muslim Brotherhood Egypt's Succession Crisis: The Political OF Liberalitation and Reform in The Middle East. London: I.B Touris Publisher. 